\title{
Downgraded by Upgrading Small-scale Traders, Urban Transformation and Spatial Reconfiguration in Post-reform Vietnam
}

\author{
Kirsten W. Endres, Max Planck Institute for Social Anthropology, Halle/Saale
}

\begin{abstract}
This article examines some of the ruptures and contestations that have emerged in the context of urban restructuring and market redevelopment policies in Hanoi, Vietnam. Public markets have become sites of contestation and struggle over the commoditization and use of public urban space: large plots of state-owned real estate in the inner city are handed over to private investment companies for development, in the process of which small-scale traders are losing their means of economic survival in the marketplace. These forms of accumulation by dispossession likewise reflect processes of social and spatial reconfiguration that exclude the urban poor and other 'uncivilized' subjects from public visibility by creating up-scaled spaces of lifestyle and consumption for the newly emerging classes of high-end consumers. Such processes of dispossession are gendered and impact on different kinds of traders in different ways.
\end{abstract}

Keywords: dispossession, Hanoi, petty commerce, public markets, urban space

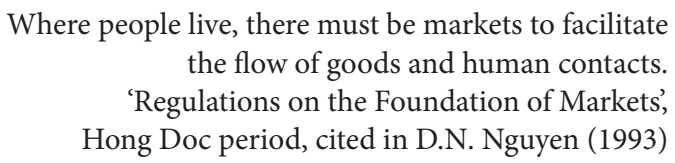

\section{Introduction}

As Fernand Braudel (2002) has pointed out in his longue durée portrayal of mercantile capitalism in fifteenth- to eighteenth-century Europe, marketplaces were once important drivers, as well as beneficiaries, of urban and economic growth. Along with the rapid spread of towns and increase in urban populations, the advance of markets 'allowed no obstacle to bar their way: they could with impunity impose on their surroundings their congestion, their rubbish and their obstinate gatherings of people. The solution adopted was to send them to the outskirts of the towns, outside the walls and towards the suburbs' (Braudel 2002: 30-31).

Vietnam's urban history has followed a similar trajectory. Since its early days as the imperial capital Thăng Long (established in the year 1010), Hanoi gradually 
transformed into a commercial centre that attracted traders and merchants from near and far. The township that took shape outside the walls of the Royal Citadel over the centuries - comprising traders and artisans, foreign merchants and members of the literati elite - eventually became known as Kẻ Chợ [market people] and formed the nucleus from which the city of Hanoi emerged (Logan 2000; T.H. Nguyen 2002). In 1682, Samuel Baron, a Hanoi-born merchant of Dutch-Vietnamese descent, observed that on the first and fifteenth of the lunar month, being the main market days, the streets of Kẻ Chợ became so crowded with sellers and buyers that one could only walk with difficulty (Dror and Taylor 2006: 202). From the late 1980s onwards, under French colonial rule, urban planning and infrastructure development subsequently turned Hanoi into a veritable 'Paris de l'Annam'. As elsewhere in the colonialized world, much of this spatial restructuring was geared towards 'the dismantling of pre-colonial social, political and economic systems' in order to achieve 'the perfect colonial society' (Logan 2000: 110).

Whereas the post-colonial period of wartime and socialist construction did not leave a strong architectural imprint on Hanoi's historic city centre, since the 1986 đổi mới reforms, Vietnam's capital has (again) been undergoing a substantial spatial transformation (Waibel 2002; Turner 2009). In present-day Hanoi, the streets are bustling with motorbikes and cars, and even the pavements are too crammed to walk. Mobile vendors who weave their way through the maze of vehicles or set up shop on the kerbsides are therefore perceived by city authorities as an impediment to the flow of traffic in the city. In order to keep up with rapid urban growth and modernization, the government has drawn up an ambitious urban master plan aimed at developing Hanoi 'to be prosperous, beautiful, civilized, modern and typical of the country, performing the functions of a major political, cultural, scientific, technological, commercial and economic centre of the whole country' and at building 'refined and civilized Hanoians typical of the Vietnamese intellect and fine traditions.' ${ }^{1}$ This civilizing project, as I shall show, includes the creation of spaces in which, in the words of Herzfeld (2006: 131), 'harmonious design would triumph over the messiness of markets and alleyways'.

Market redevelopment plans as part of urban development policies are not entirely new on the Vietnamese government's agenda, as Leshkowich (2011:282) has shown in the case of Bến Thành market in Ho Chi Minh City. What is different, however, are the scale and speed at which the modernization of public markets has been driven forward since the early 2000s. New policies were issued in the areas of distribution network planning, general market regulations and management issues, and the privatization of market construction, renovation and upgrading. ${ }^{2}$ In Hanoi, between 2007 and 2009, a number of long-standing retail markets were demolished and have since been (or are being) rebuilt with private sector investment as multi-story trade centres. I have followed the events and controversies surrounding one of these markets - Hàng Da Market - from the time of its demolition in 2008 until its resurrection as an up-scale shopping mall in 2011. When I first went to look for the relocated small-scale traders of the old market, I had difficulty finding them. In one of the side wings of the ground floor, I spotted a few (mostly deserted) relocated stalls; but where were all the others? After walking a few rounds, I gave up and asked one of the guards for directions. As it turned out, I had to leave the building in order to access the basement of the new 
glitzy mall through an entrance that was hidden from direct street view. After years of struggling for economic survival in make-shift temporary stalls until their relocation in the basement of the new mall, Hàng Da market vendors were now plying their merchandise, quite uncomfortably, in a gloomy underground space where they had to put up with the stale smell emanating from the air-conditioning system, all while having to pay higher monthly fees and suffering from the lack and loss of customers and consequently a decline in income.

This article draws on a variety of sources in order to shed light on the ruptures and discontinuities that have impacted on Vietnamese small-scale traders in the context of urban restructuring and market redevelopment policies, including notes from unstructured observations and informal talks with Hàng Da market vendors before and after relocation (i.e., between the years 2008 and 2011), documentary film and online media reports. A questionnaire survey among a representative sample of vendors across different sections of the market, conducted in October 2012 with the help of research assistants, provided further answers to the question of how stallholders rate their (dis) satisfaction with the situation before and after the construction of the new market.

In the light of Massey's (2005: 9) conceptualization of space as a product of interrelations that is always 'under construction', I argue that the ruptures inflicted upon small-scale traders by urban market redevelopment reflect wider processes of social and spatial reconfiguration currently taking place in Vietnam. As Fernandes (2004: 2421) has pointed out in the case of Mumbai, such processes of urban reconfiguration generate 'a form of class-based socio-spatial segregation' that excludes the urban poor and other 'uncivilized' subjects from public visibility by creating upscale spaces of lifestyle and consumption for the newly emerging class of high-end consumers. Yet spatial transformations are never complete, nor are they entirely predictable or certain in their outcome (Öz and Eder 2012). Instead, they are shaped by and give shape to multifarious contestations over the 'right to the city' (Harvey 2003; Lefebvre 2006), including 'deep-seated struggles over the control and use of urban space - space which is now a commodity growing steadily scarcer and more valuable every year' (Lessinger 1988: 171; see also Spector 2008).

Such struggles have been taking place at an increasing rate and scale in Vietnam's current era: large plots of state-owned real estate in the inner city are handed over to private investment companies for development, in the process of which thousands of small traders are dispossessed of their means of economic survival in the marketplace. Following David Harvey (2003: 146), I maintain that the processes of 'accumulation by dispossession' that mark the discontinuities faced by Hàng Da marketeers also entail the 'appropriation and co-optation of pre-existing cultural and social achievements', including 'pre-capitalist skills, social relations, knowledges, habits of mind, and beliefs'. Such processes of dispossession are not only profoundly gendered (given that marketplaces and other sites of small-scale trade are overwhelmingly femaledominated spaces), but also impact on different kinds of traders in different, and not always predictable, ways. 


\section{The Spatiality of Small-scale Trade}

Towards the end of the nineteenth century, a French observer described small-scale trading practices in colonial Hanoi as follows: 'It costs nothing to set up a market, it only requires you to sit down in the street, on the ground, with your merchandise on a piece of cloth or in a basket, or in the dust if you don't mind the dirt' (Bourde 1885: 287, my translation). In contemporary Hanoi, such use of public space for the display and sale of goods is still a familiar sight. In common with many post-socialist states in Central and Eastern Europe, Vietnam's economic liberalization in the late 1980s first of all triggered an unprecedented revival of small-scale female-dominated trade (Pettus 2003; Leshkowich 2005), part of which in fact emerged out of the large shadow economy that had sustained Vietnam during wartime and the post-war decade of severe economic shortage prior to the 'renovation' policy launched in 1986 (Freeman 1996). As the streets gradually filled up with honking motorbikes and - more recently - luxury cars, the pavements were taken over by small shops, street food restaurants, and (mostly migrant and female) street vendors (Drummond 2000; Jerneck 2010). The latter are generally mobile in the sense that they can easily move their goods around the city, by either carrying them around in baskets suspended from shoulder poles, on bicycles, or on pushcarts. They are, however, not constantly on the move, but rather tend to cluster around particular spaces of flows within the city at certain times of the day when they are most likely to attract clients in need of their goods. Street food vendors, for example, may cluster in the vicinity of larger office complexes, whereas snack vendors gather around recreational and religious sites. Vendors of fresh produce tend to agglomerate at certain street corners or in alleyways where they form so-called chợ cóc [frog markets], during certain hours - often in the late afternoon, when clients are on their way home from work or from picking up their children from school. Moreover, street vendors tend to cluster in close proximity to roofed markets. They are usually found in the same spots to which they may, over time, claim an exclusive (informal) right against any newcomers on the scene, and some even mark their vending space by painting their names onto the kerbstone or by demarcating a certain spot in the street.

As Alfred Gell (1982: 472) has aptly shown through his structural analysis of Dhorai Market (India), the spatial layout of a traditional market 'provides a mapping, in space, time and in the form of market interactions, for the gamut of social relations found in the wider society' (original emphasis). From such a spatial perspective, vendors who sell their goods from a wicker basket on the ground in an unstable location are clearly situated at the bottom rung of Hanoi's market hierarchy. In addition, such forms of predominantly female commercial activity have raised the Vietnamese government's concern about expressions of public disorder and economic backwardness. Unlicensed small-scale trade outside the confines of fixed marketplaces has thus become a major target of government campaigns aimed at instituting urban order and a civilized urban lifestyle since the early 1990s (Harms 2009; Leshkowich 2005). Many of the rules and standards imposed by recent political economy changes run counter to the social norms that govern the spatial and temporal organization of 'traditional' economic activity and therefore meet with various forms of resentment and resistance by those affected (Turner and Schoenberger 2011; Kurfürst 2012; Turner 2013). Moreover, rather than providing a consistent legal basis for their economic activity, the maze of rules and 
regulations relevant to Vietnamese small-scale traders does little in the way of reducing uncertainty. On the contrary, regulatory uncertainty (as well as coercion) has evolved as an efficient means by which the Vietnamese state exercises power over its citizens (Gainsborough 2010). In her research with street vendors in Hanoi, Lisa Barthelmes found that the possibility of a police raid, which usually results in the confiscation of goods and imposition of a fine, is the most antagonizing part of their daily routine [personal communication, December 2013]. The lack of predictability as to when and where a mobile law-enforcement team will chase after them, and what kind of treatment and penalty they are to expect if caught, further enhances the precarious economic situation of mobile vendors, whose semi-legal status as rural-to-urban migrant workers already sets significant limits to their livelihood options. Due to their high vulnerability and limited financial capacity, street vendors have limited chances of upward mobility, and few of them manage to secure themselves a place in a roofed market. ${ }^{3}$

In Hanoi, the first roofed market halls were constructed under French colonial rule (e.g., Đông Xuân Market, 1889) and have since become institutionalized in urban centres throughout Vietnam. Since the open-door policy was introduced in 1986, many market buildings that had fallen into disrepair during the so-called subsidy period (thờ kỳ bao cấp) were renovated or rebuilt.

Hàng Da market, though long established as an open-air market in Hanoi's old quarter, was redesigned as a roofed market in 1989 and provided space and income opportunities for over five hundred vendors of varied backgrounds. Whereas private trade had been considered as unproductive and tolerated only as a small-scale survival strategy during the state-planned economy (Abrami 2002), it now became a viable means for retirees and laid-off state employees to make a living. According to Pettus (2003: 194), vendors in the market's large fabric section included:

former factory workers, state sellers, college students, teachers, and Youth Union activists. Some had been 'guest workers' in eastern Europe in the 1980s. Many of the sellers' husbands were unemployed state workers or underemployed civil servants; some husbands ran small business enterprises (such as auto parts and repair shops) in other parts of the city, while others assisted their wives by transporting fabric from the wholesaler to the market stall.

Strictly speaking, traders in Vietnam's state-run markets do not own their stalls but have rental agreements with the market management board based on legal stipulations. These rental agreements are usually signed for a certain time period. The reality, however, is more complicated. First, vendors in public markets need to formalize their trades at the business registration office (under the Department of Planning and Investment) and register with the tax authority. Second, traders may invest capital into the construction of state-run markets by paying their stall rental fees for a specified time in advance (under current provisions in Hanoi, the maximum duration of rent is ten years). Third, stall rental contracts can also be auctioned (đấu giá, đấu thâu) to the highest bidder in case the demand exceeds the availability of stalls in a newly constructed market or if a stall in an established market falls vacant. ${ }^{4}$ Many stallholders in Vietnam's public markets have thus invested large sums into bidding for the right to operate a stall. This right is transferable, i.e., a vendor can also 'sell' or sub-let the stall 
to someone else. Moreover, it can be used as collateral for a bank loan in order to raise capital for trading purposes. A stall in a roofed market therefore represents an asset value even though the trader is not its proper owner. ${ }^{5}$

In the course of Hanoi's ongoing urban transformation, however, the asset value of a stall in a public market has started to crumble. Whereas small-scale trade outside the confines of fixed marketplaces has long been viewed by the government as detrimental to a civilized urban order and lifestyle, development plans geared towards the renovation of the capital's wholesale and retail network now promote the use of modern shopping facilities in order to 'raise the people's cultural standard and increase their level of knowledge about the market economy.' In other words, whereas street vendors risk being chased off their vending locations and having their goods and shoulder poles confiscated, recent strategies of urban spatial reconfiguration have dispossessed market vendors by other means - namely, by making them invisible.

\section{Spatial Reconfiguration: The Example of Hàng Da Market}

When the market management board officially announced in 2007 that Hàng Da Market was going to be rebuilt, hundreds of petty traders felt hard-pressed (búc xúc; see Xuân Long 2007). The term búc xúc has been aptly described by Harms (2012: 739) as 'feeling pressed by oppressive force into a sense of exasperated distress'. Although such plans had been underway since 2001, the announcement apparently took the vendors by surprise. Their most pressing concern was that the design of the planned civilized and modern 'commercial centre' (which at that time had not yet been publicized by the private investor) would not meet their interests and needs (ibid.). Back in 1989, when the market was first constructed, many Hàng Da traders had contributed to the market construction costs in order to obtain a stall the size of about three square metres. A liquor vendor quoted by Xuân Long (2008) reminisces that her family sold a house for thirteen taels of gold in order to free up capital. ${ }^{7}$ The vendor invested two-thirds of the proceeds from selling the house into the market and used the remaining third for buying a piece of land and building a new house. Whereas the latter is now allegedly worth ten billion đông (about 350,000 Euros), the vendor finds the current value of her market stall difficult to estimate. Other vendors also invested capital into the market's construction (góp vốn xây dựng chợ), the amount of which varied according to the location of their stalls. Although these contributions were allegedly credited against the monthly stall rental fees, the vendors argued that their overall investments far exceeded the credits they had received over the years until the decision to upgrade the market was taken. Moreover, many vendors regarded this decision as a sign of disregard for their contributions to the construction of a state-managed public market owned by the people. As one stallholder quoted by online media reasoned, 'By entrusting a company with rebuilding the market, the city [of Hanoi] flicks off the people's contributions in labour like dust. Hundreds of citizens have contributed money to build the market, but nobody considers our interests or our compensation when it comes to pulling it down!' (Xuân Long 2008).

I started following the events surrounding Hàng Da market in August 2009 during an exploratory trip to Vietnam in preparation for my research on markets. The vendors 
had already been relocated to a long row of tin-roofed temporary stalls along a major through street, and the old market had given way to a huge construction site. When I talked to some of the vendors, I received quite uniform answers to my questions: those who had 'bought' their place in the old markets had been promised a stall in the new market as a replacement without additional costs. Despite this, because the fees were expected to be higher than previously, they anticipated that they would probably have to raise their prices in order to make ends meet. Due to the recent economic downturn, it had already become more difficult to make a good profit from trading, and the vendors were worried about the future, as they felt unsure that they would be able to sell their goods for as much profit in the new market as they used to.

More than a year later, in December 2010, the construction of the new Hàng Da commercial centre was completed. While the developers - an alliance between two joint stock companies - were looking for high-class retail tenants in the modern plaza, the former vendors started to occupy the new spaces that had been assigned to them. ${ }^{8}$ What puzzled me most during my first visit was that the booths I found in one of the side wings of the ground floor clearly lacked a concept of modern market stall design. Some stalls had notices attached to the flimsy partition panels saying 'for sale' which I read as a first sign that something was going awry. It was, however, not until my next visit to Hanoi in December 2011 that I could get a clearer picture of the conditions in which the majority of the former Hàng Da vendors had been operating their businesses since they had moved into the modern mall, now ostentatiously renamed Hàng Da Galleria. Rather than being relocated to the ground floor of the building, as promised by the developers, most of the vendors had found themselves relegated to the stuffy basement. Whereas gleaming escalators lead from the spacious entrance hall to the luxury fashion stores selling designer labels on the upper floors, the staircase leading to the basement was nowhere to be found. As it turned out, the underground market could only be reached through the back entrance of the building, or through a narrow corridor next to the underground parking ramp. Not only had the former Hàng Da vendors become invisible to the outside world, but they had also been cut off from easy accessibility within the building.

Michael DiGregorio's film Hanoi Public Market (2012) gives a lively insight into the ways in which the market vendors have been affected by the spatial reconfiguration of Hàng Da Galleria. The vendors had apparently been misled by a terminological ambiguity concerning the word for 'ground floor' used by the developers. 'When they knocked down the old market, they told us that we would be put on the ground floor (tầng trêt $)$,' one vendor explains. 'We understand clearly that "ground floor" means the same foundation as the old market, and "first floor" is above its ceiling. ' So we were quite shocked to hear that the basement (hâm) is the ground floor' (DiGregorio 2012). Yet the vendors' complaints were to no avail. 'Some of us struggled at a government office for a month, but in the end, we were still forced down here,' an elderly woman told the filmmaker. 'Frankly speaking, we've been sold out' (ibid.).

Without air conditioners, the stale air (and the heat in summer) in the basement would be even harder to bear. 'But using air conditioners raises our costs', vendors complain. 'Our electricity bills used to be only several thousand dong per month. Now we pay several hundred thousand dong. It's just too expensive' (ibid.). Stallholders are 


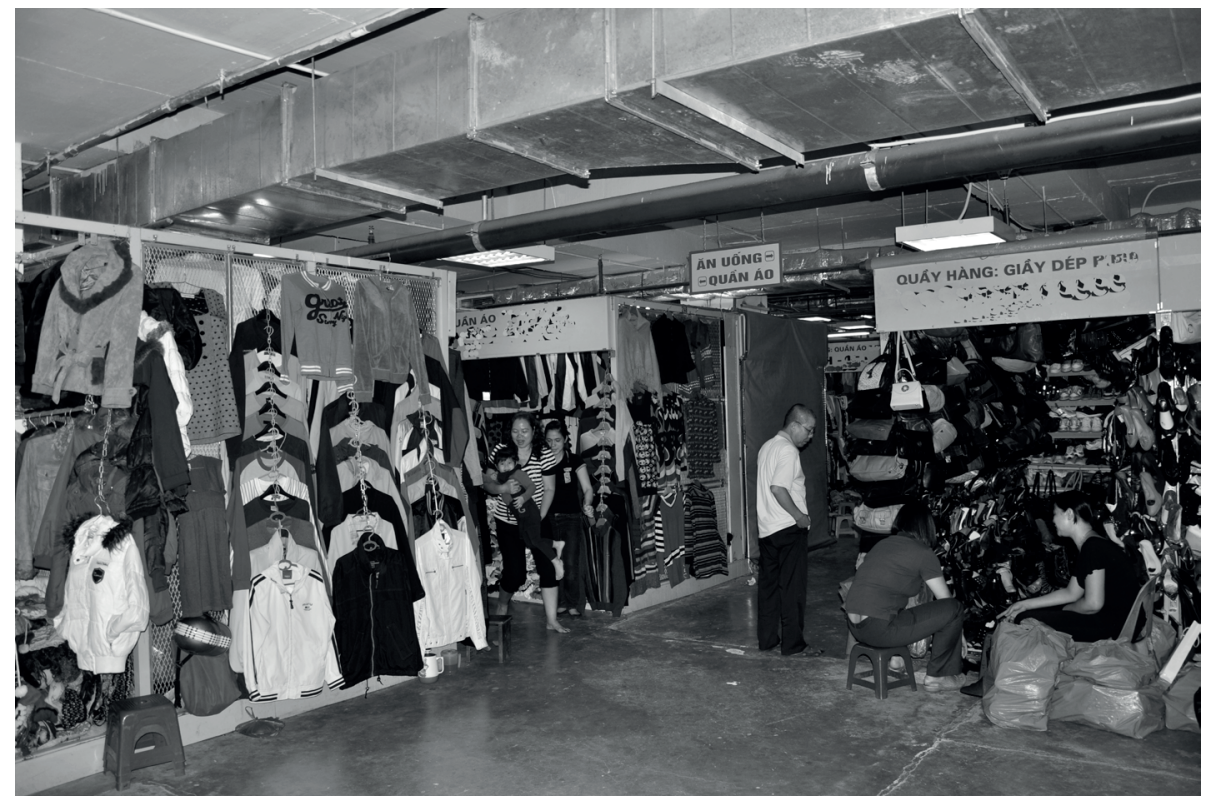

Figure 1: Used clothes vendors in the basement of Hàng Da market (photo by the author, November 2011). The signboards above the stalls usually display the owners' names and telephone numbers. This photo has been altered in order to protect the identity of stallholders.

held liable for these and other fees (for security, hygiene, etc.) whether or not they operate their stalls, which is why many of them remain in business even if their profits are low. Others try to save costs by cutting down on their own meals. 'In the old market, I used to have meat at lunch,' one of the clothes vendors reminisced to me. 'Now I eat tofu instead' (conversation with the author, 28 November 2011).

A survey conducted in October 2012 among 150 Hàng Da market vendors shows the average degree of satisfaction in the old market versus the new market with regard to a number of issues (see figure 2). ${ }^{10}$ With the exception of hygiene and safety, satisfaction with the conditions in the new market is markedly lower than in the old market. The most pressing concern of the vendors, however, boils down to a significant decline in earnings due to the lack of customers - who (like myself) cannot find either the entrance or parking in close proximity and thus decide to shop elsewhere. As one of the vendors put it: 'The new market is cleaner and more civilized than before, but all this is less important than securing an income. Whereas in former times her stall was allegedly patronized by thirty to forty customers on an average day, she estimates that nowadays the amount of clients does not exceed that number in a whole month. 'I feel even more miserable than during the state-subsidized [centrally-planned] period,' the former state employee moans. 'At least I had a salary in those days.'

Yet lower profits are not the only consequence of the vendors' spatial exclusion from economic activities that are deemed incompatible with a civilized, modern urban lifestyle. Asked about the current market value of their stalls, many vendors claimed 


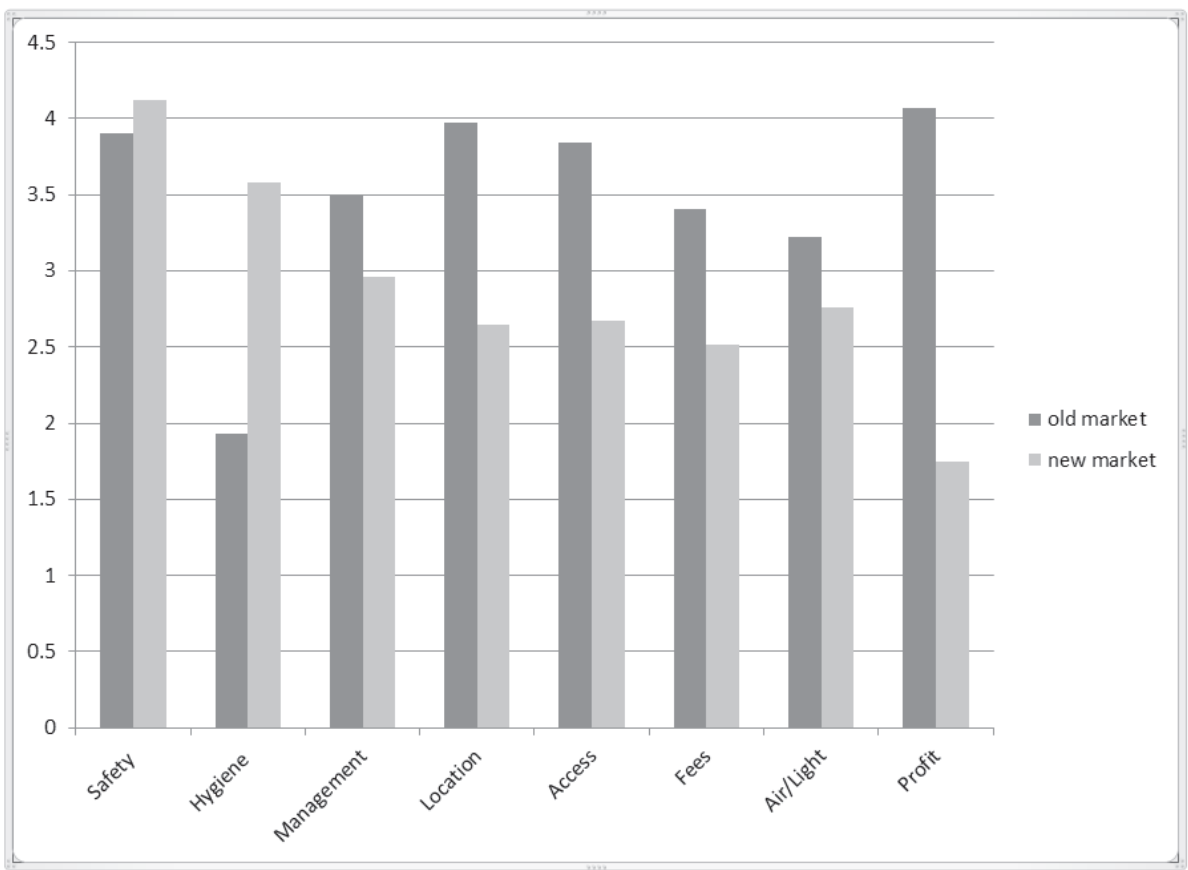

Figure 2: Degree of satisfaction with conditions in the old versus the new market ( $1=$ highly dissatisfied; 5 = highly satisfied)

they had no idea. 'Who wants to buy a stall in a deserted market anyway?' one of them mused. 'Right after relocation there was still a high demand for stalls, but now that we don't sell anything from morning until evening - no one is interested in buying anymore'. Many vendors therefore feel stuck with their stalls, because resigning from their rental contracts would mean that they would lose whatever capital they invested into obtaining a stall in the market. Since the market has been privatized, the vendors also feel that their concerns are neither heard nor addressed adequately. 'The developers are the ones who pay, so they have all the rights,' one of the vendors portrayed in Hanoi Public Market suggests. 'That's why they never listen to us. They just do what is profitable for themselves' (DiGregorio 2012). The vendor's assessment of the situation reveals that she has understood the free-market principles of private investment quite well. 'Frankly speaking,' she says, 'the government already sold them 49-50 year leases. Now they have to try to generate income to recover their investment as quickly as possible. They have to arrange spots for our shops in this market. But whether we succeed or not is not their concern' (ibid.).

\section{Conclusion: The Ironies of Urban Restructuring}

In a recent article, Harms (2013b) refers to the social interpretations of and responses to land clearance and housing demolition for infrastructure projects as a form of 'social demolition' that 'releases latent value in things, brings them into circulation and makes 
them part of an eminently social landscape of moral contest and exchange' (ibid.: 67). The 'elimination' (xóa bỏ) of traditional markets in Hanoi has had a similar effect. According to one online media commentator, their transformation into 'frosty' (lanh lùng) commercial centres and supermarkets 'devoid of emotion' ( $v \hat{o}$ cảm) 'entails a loss of economic, social/cultural and moral (tinh thân) values inherent to the marketplace' (Trần 2012, my translation).

But the story of Hàng Da market has also taken a number of ironic twists. First, several Hanoi markets that had been 'upgraded' into shopping malls ultimately turned out to be a failed investment. A year and a half after the grand opening of Hàng Da Galleria, many high-end shops on the upper floors had already shut down or moved to other areas of the city. Reports in English-language online news media recently carried headlines such as 'Hanoi's plan to develop modern markets fails completely'11 and 'Investors make wrong decisions, shopping malls stay deserted. ${ }^{12}$ The reasons given for the failure include an oversupply of mall space in Hanoi, a lack of purchasing power in the population, the shopping habits of the Hanoians, and a general preference for 'traditional' forms of retailing.

The second irony is that the street vendors clustering around the new Hàng Da market emerged as the (temporary) profiteers from the spatial relegation of the market vendors to the basement, which in turn is seen by the latter as aggravating their already precarious situation even further. As already indicated above, street vending offers a convenient way for customers to stop-and-shop directly from their motorbikes. Besides being 'indispensable for urban mobility' (Truitt 2008: 9), motorbikes have also been 'instrumental in class formation [...] as symbols of purchasing power, embodiments of individual freedom, and flexible forms of mobility' (ibid., 15) in urban Vietnam. The demands of ever-busier lifestyles (as well as ingrained habits) have resulted in a general reluctance to interrupt the flow of movement from one destination to the next, and whatever can be accomplished without having to park the vehicle in a designated parking area (which, moreover, implies having to pay a parking fee) is felt to save time, energy and money. Even roofed markets are sometimes accessed on a motorbike, despite signs forbidding vehicles. This, however, is not possible at Hàng Da market. As parking in front of the market is not allowed, customers are forced to take their vehicles to the overcrowded parking garage that hardly has enough space to accommodate the vendors' motorbikes. Moreover, the parking fee (ranging between 3000 and 6000 dông) may even be higher than the price for a few items needed to complete a meal. 'Vietnamese people prioritise convenience,' one elderly Phố Cổ vendor aptly observes. 'When shopping, they neither want to park a bike nor walk downstairs. People will only come down here if they can't find what they want up there. That's the only way we can sell anything' (DiGregorio 2012).

In The Great Transformation, first published in 1944, Karl Polanyi cautioned against the idea of the free market (i.e., free enterprise and private ownership) as the essence of human freedom, as this may ultimately come to mean 'the fullness of freedom for those whose income, leisure, and security need no enhancing, and a mere pittance of liberty for the people, who may in vain attempt to make use of their democratic rights to gain shelter from the power of owners of property' (Polanyi 2001 [1944]: 265). Such have been the effects of neoliberal restructuring in many parts of the world, including 
Europe, and we can see evidence of its first seeds taking root in Vietnam today (Kim 2011; Harms 2013a; Labbé and Musil 2014).

One of the most visible outcomes of neoliberal restructuring is the contested emergence of urban landscapes of inequality marked by spatial exclusion and segregation (Sibley 1995; Brenner and Theodore 2002). As I have suggested in this article, ongoing processes of urban socio-spatial transformation, entailing accumulation by dispossession, have significantly affected the economic viability of small-scale traders in Hanoi's inner city, exposing them to a higher level of economic uncertainty. Whereas itinerant street vendors manage to persist despite prohibition signs and regular interventions by local authorities, stallholders in roofed public markets are confronted with the spatial exclusion from their means of livelihood in somewhat more profound ways. Small-scale traders therefore 'expose the central contradictions of a socialist state based on equity pursuing capitalist policies that dispossess some of its most vulnerable citizens' (Leshkowich 2005: 204). Unlike street vendors, who move around the city in flexible patterns, market vendors depend on permanent retail spaces and are vulnerable to increases in stall fees and customers' shifting loyalties. At Hàng Da market, the 'upgrading' of old-style markets has 'downgraded' the longestablished vendors to make space for high-end shopping facilities that are deemed attractive for the new urban elite and upper middle-class (Drummond 2012). Rather than enjoying the comfort of modern architecture and design and benefitting from an increase in value of their assets in the marketplace, they now see themselves stuck with the responsibility of paying higher fees and bills despite the fact that their profits from trade have significantly decreased. The ways in which dispossession plays out differently for itinerant street vendors and market stallholders thus also underlines a seemingly obvious, but frequently overlooked fact - namely, that the most egregious forms of dispossession often follow directly on the heels of the normalization of property rights. ${ }^{13}$

On a more positive note, the contestations surrounding the new Hàng Da mall and other failed market redevelopment projects apparently contributed to a rethinking of Hanoi's current market development plans. 'Hanoi to not eliminate traditional markets in 5-7 more years ${ }^{14}$ was one of the headlines that flashed on the news in July 2013. Whereas this decision will not change the situation for the relocated Hàng Da vendors, their expressions of discontent, publicized by the media and discussed in public forums organized by non-governmental organizations (Geertman 2011), contributed to a (partial) renegotiation of Hanoi's ambitious market upgrading programme and halted plans for the 'upgrading' of two remaining old-style markets into shopping complexes. Meanwhile, the Hàng Da market vendors keep hoping that things will eventually turn out for the better - hope, after all, has been a major driving force in their 'underground' persistence. While their futures as small-scale traders remain uncertain, their case reminds us that space and place, too, are always in the making, shaped by and giving shape to changing social processes, power relations and economic practices. 


\section{Acknowledgements}

Research for this article was conducted as part of a cooperative agreement between the Max Planck Institute for Social Anthropology, Halle/S., Germany, and the Institute of Anthropology, VASS, Hanoi. Many thanks go to Nguyễn Thị Thanh Bình for organizing and supervising the survey, and to Phạm Thị Thu Hà, Nguyễn Thẩm Thu Hà and Trần Thị Mai Lan for conducting interviews at the market. I also thank the anonymous reviewers for their insightful comments and valuable suggestions for extending the argument.

\section{Notes}

1. Decision No. 1081/QD-TTg of 6 July 2011, approving the master plan on socioeconomic development of Hanoi City up to 2020, with orientations toward 2030.

2. See for example Decree No. 02/2003/ND-CP of 14 January 2003, on the development and management of marketplaces (Nghị định 02/2003/NĐ-CP về phát triển và quản lý chợ); Decision 012/2007/QD-BCT of 26, December 2007, approving the master plan of developing the nationwide market network up to 2010, with orientations towards 2020 (Quyết định số 012/2007/QĐ-BCT ngày 26 tháng 12 năm 2007, Phê duyệt quy hoạch tổng thể phát triễn mạng lưới chợ trên phạm vi toàn quốc đến năm 2010 và định hướng đến năm 2020); for Hanoi see also Decision 5058/QD-UBND of 5 November 2012, approving the plan for the wholesale and retail network in Hanoi up to 2020, with a vision towards 2030 (Quyết định 5058/QĐ-UBND năm 2012 phê duyệt Quy hoạch mạng lưới bán buôn, lẻ trên địa bàn Thành phố Hà Nội đến năm 2020, định hướng đến năm 2030).

3. Obtaining a stall in a roofed market may not be the main aspiration of every street vendor though. Whereas some migrant vendors only engage in temporary/seasonal vending activities, others may prefer the relative freedom that street vending provides.

4. See Article 13 of the 'Regulation on market development and management in Hanoi', approved by decision 12/2012/QĐ/UBND, available online at <http://vanban.chinhphu.vn/portal/page/portal/ chinhphu/hethongvanban?class_id=1\&_page $=1 \&$ mode $=$ detail\&document_id $=163995>($ accessed 20 May 2014).

5. Here, I follow Chris Hann's suggestion to conceive of property not simply in terms of exclusive ownership, but, in a broader sense, as 'the distribution of social entitlements' (Hann 1998: 7). Hann states that: "The word "property" is best seen as directing attention to a vast field of cultural as well as social relations, to the symbolic as well as the material contexts within which things are recognized and personal as well as collective identities made' (ibid.: 5).

6. See Article 4.4 of Quyết định 5058/QĐ-UBND (full reference provided in endnote 3).

7. In Vietnam, one tael of gold (cây vàng) equals 37.5 grams

8. According to the current market management, there are currently 594 stallholders at Hàng Da market, 140 of whom 'have not yet started their business' (chia ra kinh doanh). Some of the latter have apparently sublet their vending spaces to neighboring stallholders.

9. This confusion may have been caused by the fact that in Vietnam the ground floor is commonly referred to as the first floor. It remains unclear whether the developers mistook the architectural term tâng trệt (ground floor) as the basement or whether the vendors were purposefully made to believe that their stalls would be relocated to the ground floor.

10. The survey was conducted in all major sections of the market (e.g., fresh and dry produce, garments and shoes, household items and ceramics, and liquors). The majority of the 151 interviewees were female (148), aged between 58 and 37 years old (116 respondents), and had been stallholders in the market since at least ten years before market reconstruction started in 2008 (107 respondents).

11. <http://english.vietnamnet.vn/fms/business/22189/hanoi-s-plan-to-develop-modern-markets-failscompletely.html $>$ (accessed 7 February 2014).

12. <http://english.vietnamnet.vn/fms/business/72620/investors-make-wrong-decisions--shopping-mallsstay-deserted.html> (accessed 7 February 2014). 
13. I am most grateful to one of the reviewers for pointing me in this direction.

14. <http://english.vietnamnet.vn/fms/business/78557/hanoi-to-not-eliminate-traditional-markets-in-57-more-years.html> (accessed 7 February 2014).

\section{References}

Abrami, R.M. 2002. Just a Peasant: Economy and Legacy in Northern Vietnam. In Post-Socialist Peasant? Rural and Urban Constructions of Identity in Eastern Europe, East Asia and the Former Soviet Union (eds) P. Leonard \& D. Kaneff, 94-116. Basingstoke: Palgrave.

Bourde, P. 1885. De Paris au Tonkin. Paris: Calmann Lévy.

Braudel, F. 2002 [1982]. The Wheels of Commerce: Civilization \& Capitalism 15 $5^{\text {th }}-18^{\text {th }}$ Century, Volume 2. London: Phoenix Press.

Brenner, N., \& N. Theodore (eds) 2002. Spaces of Neoliberalism: Urban Restructuring in North America and Western Europe. Malden: Blackwell Publishing.

DiGregorio, M. (dir.) 2012. Hanoi Public Market / Chợ Dân sinh Hà Nội. Hanoi: Redbridge TV \& Film Production.

Dror, O., \& K.W. Taylor (eds and annotators) 2006. Views of Seventeenth-Century Vietnam: Christoforo Borri on Cochinchina \& Samuel Baron on Tonkin. Ithaca: Southeast Asia Program Publications, Cornell University.

Drummond, L.B.W. 2000. Street Scenes: Practices of Public and Private Space in Urban Vietnam. Urban Studies 37(12): 2377-2391.

Drummond, L.B.W. 2012. Middle Class Landscapes in a Transforming City: Hanoi in the 21st Century. In The Reinvention of Distinction: Modernity and the Middle Class in Urban Vietnam (eds) V. Nguyen-Marshall, L.B.W. Drummond \& D. Bélanger, 79-93. Dordrecht: Springer.

Fernandes, L. 2004. The Politics of Forgetting: Class Politics, State Power and the Restructuring of Urban Space in India. Urban Studies 41(12): 2415-2430.

Freeman, D.B. 1996. Doi Moi Policy and the Small-Enterprise Boom in Ho Chi Minh City, Vietnam. Geographical Review 86(2): 178-197.

Gainsborough, M. 2010. Vietnam: Rethinking the State. London: Zed Books; Chiang Mai: Silkworm.

Gell, A. 1982. The Market Wheel: Symbolic Aspects of an Indian Tribal Market. Man 17(3): 470-491.

Hann, Chris. 1998. Introduction: The Embeddedness of Property. In Property Relations: Renewing the Anthropological Tradition (ed.) C. Hann, 1-47. New York: Cambridge University Press.

Geertman, S. 2011. Hanoi - Fresh Markets, a Way of Life and Public Health under Threat. Keynote lecture presented at Public Forum Public Markets in the Corporate City, Hanoi. Available online at <http://www.healthbridge.ca/Fresh\%20Markets\%20-\%20Full\%20 paper\%20Stephanie\%20Geertman\%20Full\%20paper.pdf> (accessed 25 February 2014).

Harms, E. 2009. Vietnam's Civilizing Process and the Retreat from the Street: A Turtle's Eye View from Ho Chi Minh City. City \& Society 21(2): 182-106.

Harms, E. 2012. Beauty as Control in the New Saigon: Eviction, New Urban Zones, and Atomized Dissent in a Southeast Asian City. American Ethnologist 39(4): 735750.

Harms, E. 2013a. Eviction Time in the New Saigon: Temporalities of Displacement in the Rubble of Development. Cultural Anthropology 28(2): 344-368.

Harms, E. 2013b. Social Demolition: Creative Destruction and the Production of Value in Vietnamese Land Clearance. In State, Society and the Market in Contemporary Vietnam (eds) H.-T. Ho Tai \& M. Sidel, 55-68. Abingdon: Routledge. 
Harvey, D. 2003. The New Imperialism. Oxford: Oxford University Press.

Herzfeld, M. 2006. Spatial Cleansing: Monumental Vacuity and the Idea of the West. Journal of Material Culture 11(1-2): 127-149.

Jerneck, Anne. 2010. Globalization, Growth and Gender: Poor Workers and Vendors in Urban Vietnam. In Gendered Inequalities in Asia: Configuring, Contesting and Recognizing Women and Men (ed.) H. Rydstrøm, 99-123. Copenhagen: NIAS Press.

Kim, A.M. 2011. Talking Back: The Role of Narrative in Vietnam's Recent Land Compensation. Urban Studies 48(3): 493-508.

Kurfürst, S. 2012. Informality as a Strategy: Street Traders in Hanoi Facing Constant Insecurity. In Urban Informalities. Reflections on the Formal and Informal (eds) C. McFarlane \& M. Waibel, 89-111. Burlington, VT: Ashgate.

Labbé, D. \& C. Musil. 2014. Periurban Land Redevelopment in Vietnam under Market Socialism. Urban Studies 51(6): 1146-1161.

Lefebvre, H. 2006. Writings on Cities (selected, translated and introduced by E. Kofman). Oxford: Blackwell.

Leshkowich, A.M. 2005. Feminine Disorder: State Campaigns against Street Traders in Socialist and Late-Socialist Việt Nam, in Le Việt Nam au Féminin. Việt Nam: Women's Realities (eds) G. Bousquet \& N. Taylor, 187-207. Paris: Les Indes Savantes.

Leshkowich, A.M. 2011. Making Class and Gender: (Market) Socialist Enframing of Traders in Ho Chi Minh City. American Anthropologist 113(2): 277-290.

Lessinger, J. 1988. Trader vs. Developer: The Market Relocation Issue in an Indian City. In Traders Versus the State (ed.) G. Clark, 139-164. Boulder, CO: Westview Press.

Logan, W.S. 2000. Hanoi: Biography of a City. Sydney: Select Publishing/UNSW Press.

Massey, D. 2005. For Space. London: Blackwell Publishing.

Nguyen Duc Nghinh. 1993. Markets and Villages. In The Traditional Village in Vietnam, 315376. Hanoi: The Gioi Publishers.

Nguyen Thua Hy. 2002. Economic History of Hanoi in the 17th, 18th and 19th Centuries. Hanoi: National Political Publishing House.

Öz, Ö., \& M. Eder. 2012. Rendering Istanbul's Periodic Bazaars Invisible: Reflections on Urban Transformation and Contested Space. International Journal of Urban and Regional Research 36(2): 297-314.

Pettus, A. 2003 Between Sacrifice and Desire: National Identity and the Governing of Femininity in Vietnam. New York: Routledge.

Polanyi, K. 2001 [1944]. The Great Transformation: The Political and Economic Origins of Our Time. Boston: Beacon Press.

Sibley, D. 1995. Geographies of Exclusion. Abingdon: Routledge.

Spector, R.A. 2008. Bazaar Politics: The Fate of Marketplaces in Kazakhstan. Problems of PostCommunism 55(6): 42-53.

Trân Thị Kiều Thanh Hà. 2012. Xóa bỏ chợ trong đô thị để xây siêu thị - Phú quý giật lùi? [Eliminating Markets to Build Supermarkets - Prosperity Going Backward?]. Dân Trí online, 10 April 2012, available online at <http://dantri.com.vn/ban-doc/xoa-bo-chotrong-do-thi-de-xay-sieu-thi-phu-quy-giat-lui-583857.htm> (accessed 12 March 2013).

Truitt, A. 2008. On the Back of a Motorbike: Middle-Class Mobility in Ho Chi Minh City, Vietnam. American Ethnologist 35(1): 3-19.

Turner, S. 2009. Hanoi's Ancient Quarter Traders: Resilient Livelihoods in a Rapidly Transforming City. Urban Studies 46(5-6): 1203-1221.

Turner, S. 2013. Appropriate Space? An Everyday Politics of Street Vendor Negotiations in Hanoi, Vietnam. In Street Economies in the Urban Global South (eds) K. Tranberg Hansen, W.E. Little \& B.L. Milgram, 137-156. Santa Fe: School for Advanced Research Press. 
Turner, S., \& L. Schoenberger. 2011. Street Vendor Livelihoods and Everyday Politics in Hanoi, Vietnam: The Seeds of a Diverse Economy? Urban Studies 49(5): 1027-1044.

Waibel, M. 2002. Stadtentwicklung von Hanoi. Unter besonderer Berücksichtigung der Auswirkungen der Doi Moi Reformen auf den Handel im innerstädtischen 36-GassenGebiet. Frankfurt/M.: Peter Lang.

Xuân Long. 2007. Hàng trăm hộ tiểu thương chợ Hàng Da bức xúc [Hundreds of Hàng Da petty traders feel hard-pressed]. Lao Động online, 17 August 2007, retrieved from http:// www.laodong.com.vn/Utilities/PrintView.aspx?ID=51076 (accessed 30 June 2009).

Xuân Long. 2008. 500 tiểu thương bị "ngó lơ" lợi ích? [The interests of 500 petty traders have been 'ignored'?]. Tuổi Trẻ online, 1 May 2008, available at <http://tuoitre.vn/Chinh-tri-Xahoi/255361/500-tieu-thuong-bi-ngo-lo-loi-ich.html> (accessed 20 May 2014).

Kirsten W. Endres is Head of a Research Group in the Department 'Resilience and Transformation in Eurasia', Max Planck Institute for Social Anthropology, Halle/ Saale. Her recent publications include 'Making Law: Small-scale Trade and Corrupt Exceptions at the Vietnam-China Border', American Anthropologist 116(3), September 2014. 